\title{
Phytochemical screening and biological activities of pakoba (Syzygium luzonense) stem bark ethanol extract
}

\author{
MARIO WALEAN ${ }^{1, \vartheta}$, ROSTINA MELPIN ${ }^{1}$, MERVINA RONDONUWU ${ }^{1}$, KINZIE FELICIANO PINONTOAN ${ }^{1}$, \\ HENDRA PRATAMA MALIANGKAY ${ }^{2}$, MELI ASTRIANI ${ }^{3}$ \\ ${ }^{1}$ Faculty of Science and Technology, Universitas Prisma. Jl. Pomorow No.113, Tikala Baru, Manado 95126, North Sulawesi, Indonesia. \\ "email: mario.walean@gmail.com \\ ${ }^{2}$ Pharmacy Program, Universitas Trinita. Jl. Malalayang Satu Barat, Manado 95163, North Sulawesi, Indonesia \\ ${ }^{3}$ Departement of Biology Education, Faculty of Teacher Training and Education, Universitas Muhammadiyah Palembang. Jl. Jend. Ahmad Yani 13 Ulu, \\ Palembang 30116, South Sumatra, Indonesia
}

Manuscript received: 28 March 2020. Revision accepted: 7 May 2020.

\begin{abstract}
Walean M, Melpin R, Rondonuwu M, Pinontoan KF, Maliangkay HP, Astriani M. 2020. Phytochemical screening and biological activities of pakoba (Syzygium luzonense) stem bark ethanol extract. Biodiversitas 21: 2377-2382. Pakoba (Syzygium luzonense (Merr.) Merr) as an endemic and ethnomedical plant of North Sulawesi was investigated for its phytochemical constituents and biological activities. The presence of phytochemicals constituents, antibacterial, antioxidant activities, and antihyperglycemic of pakoba stem bark ethanolic extract (PSBEE) were also investigated. Pakoba stem bark was extracted using ethanol. The extracts were evaluated for antimicrobial activity using the Kirby Bauer method, whereas antioxidant activity was determined by using 1,1-diphenyl2-picrylhydrazyl radical scavenging assay. Alloxan-induced diabetic rats investigation was used to determine the antihyperglycemic activity. The phytochemical analysis revealed that tannins, alkaloids, and flavonoids were present in PSBEE. PSBEE has potent antioxidant activity with antioxidant activity index $=1.02$. PSBEE significantly reduced the blood sugar of hyperglycemic rats with an optimum dose of $300 \mathrm{mg} / \mathrm{kgbw}$. In this study, PSBEE has weak antibacterial activity against in Escherichia coli and Staphylococcus aureus.
\end{abstract}

Keywords: Antibacterial, antihyperglycemic, antioxidant, bioactivities, pakoba, Syzygium luzonense

\section{INTRODUCTION}

Indonesia is one of 17 countries in the world with a megadiversity (Convention on Biological Diversity 2018). This potential biodiversity must not only be developed and utilized, but also more attention should be given to its sustainability aspects. In this decade, exploration of the natural product is still a trend for researchers worldwide. Decades of research have found many compounds from plants as source of new drugs (Ramadhan et al. 2019).

Bioactive exploration of plants is still the focus of world researchers by finding plant chemical compounds that possess pharmacological potentials. This is supported by the ability of plants to produce secondary metabolites called phytochemicals. Phytochemicals are defined as nonnutritive, naturally occurring biologically active, chemically derived compounds found in plant kingdoms (Alasalvar et al. 2009).

Pakoba is one of North Sulawesi's endemic plants, which has several local names, namely Kowal, Lemes, Pakowa or Pakuwa, and Pakoba. Ethnomedically, pakoba stem bark has been used by local people for the treatment of diabetes, as a medication after childbirth, drugs for kidney disease, and stomachache.

Several studies have led to a result that the administration of ethanol extract from pakoba bark toward urolithiasis rats can improve glomerular cell damage due to the administration of ethylene glycol (Walean et al. 2018).
Initial phytochemical analysis showed that ethanol extract of pakoba bark contains tannin, alkaloid, and saponin (Kinho et al. 2011).

Until currently, there has been lack of research on pakoba bioactivity. Previous studies have reported the ability of bioactivity of Syzygium species. Polyphenol extract from $S$. cumini leaves can inhibit acetylcholinesterase (AChE) and butyrylcholinesterase (BChE) in alloxan-induced diabetic mice (Ajiboye et al. 2018a). Singh et al. (2018) succeeded in isolating the mycaminose compound from $S$. cumini and succeeded in reducing the blood sugar of streptozotocin-induced white rats. Moreover, Syzygium cumini seeds also have the potential to inhibit $\alpha$-amylase, $\alpha$-glucosidase, and dipeptidyl peptidase-IV (DPP-IV) enzymes (Syama et al. 2018). Antihyperglycemic activity in other Syzygium species is demonstrated by $S$. polyanthum. S. polyanthum infusion extract can reduce the blood sugar level of white rats, induced by alloxan (Widharna et al. 2015).

The genus Syzygium is rich in bioactive compounds as antioxidants. Research conducted by El-Maati et al. (2016) reported that $S$. aromaticum ethanol extract has high antioxidant activity. The methanol extract of $S$. polynthum leaves has antioxidant potential (Hidayati et al. 2017). Syzygium cumini seeds are also reported to have a high antioxidant activity and potential as antibacterial (Kumar et al. 2017). Furthermore, seeds of S. cumini can be used as a good source of antioxidant and antibacterial (Sharma et al. 
2017). Oil from the leaves of $S$. lanceolatum is also reported to have high antioxidant activity (Muthumperuma et al. 2016).

We believe that the human resources and ethnomedical knowledge of North Sulawesi's endemic plants will be the basis for the development of raw materials for natural herbal medicines by utilizing local resources. Until recently, there has been a lack of information about the potential bioactivity of pakoba and the content of chemical compounds contained therein. This study aimed to inquire about the biological activities and to perform phytochemical screening of pakoba stem bark ethanol extract. The results of this study expected to new antidiabetic drugs from the stem bark ethanol extract of pakoba.

\section{MATERIALS AND METHODS}

\section{Plant materials and chemicals}

Materials used in this research were pakoba stem bark was obtained from natural sources in the Minahasa region, distilled water, ethanol (Merck, SG), alloxan monohydrate (Sigma-Aldrich, SG), glibenclamide (Kimia Farma, ID), methanol (Merck, SG), 2,2-diphenyl-1-picryl hydazy (DPPH) (Sigma-Aldrich, SG), ascorbic acid (Merck, SG), Escherichia coli strain ATCC 25922 and Staphylococcus aureus strain ATCC 25923, Mueller Hinton Agar (MHA) (Oxoid, UK), nutrient broth (Merck, SG).

\section{Procedures}

\section{Extraction and phytochemical analysis}

Pakoba stem bark was cleaned and then dried while protected from sunlight. It was, then ground into powder. Maceration was carried out for three days in an incubator shaker (Biosan, $\mathrm{LV}$ ) at $25^{\circ} \mathrm{C}$. The maceration results were then filtered and evaporated using a rotary evaporator (Heidolph, DE) with a temperature of $40^{\circ} \mathrm{C}$ and a pump pressure of 175 mbar by the instrument's protocol.

Alkaloid tests were carried out using three alkaloid reagents; Dragendorff, Meyer, and Wagner reagent. A flavonoid test was performed following the adapted Shinoda method. Saponin test was performed using a foam test and tannin test by adding a $5 \% \mathrm{FeCl}_{3}$ solution to the sample.

\section{Antibacterial assay}

The bacteria were cultured in a nutrient broth for 24 hours at $37^{\circ} \mathrm{C}$ before testing. The turbidity of the tested bacteria was measured using the 0.5 McFarland standard (Situmeang et al. 2019). Two hundred microliters of bacterial suspensions were applied spread onto the MHA. Antibacterial testing was performed following the Kirby Bauer method. Twenty microliters samples with concentrations according to the treatment were dripped onto paper discs on the media then placed on the test media and incubated for 24 hours at $37^{\circ} \mathrm{C}$ under aerobic conditions. After 24 hours, the diameter of the inhibition zone around the disk observed and measured using a digital micrometer in millimeter unit. PSBEE was diluted with distilled water with final concentration of $0.1 \%, 0.3 \%$,
$0.5 \%, 1 \%, 2 \%, 5 \%, 10 \%, 30 \%, 50 \%$, and cefadroxil 100 $\mathrm{mg} / \mathrm{L}$ as a positive control. The observation indicator was the amount of PSBEE growth diameter inhibition of $E$. coli and $S$. aureus.

\section{Antioxidant assay}

DPPH method as described by Hidayati et al. (2017) was used. The absorbance of the test solution was measured using a UV-Vis spectrophotometer (ParkinElmer, US) at a wavelength of $517 \mathrm{~nm}$ (Alhabsyi et al. 2014; El-Maati et al. 2016).

\section{Antihyperglycemic assay}

Wistar rat weighted around 150-200 gr, was acclimatized for 2 weeks in their homes cages. Rats were kept in room condition, each 12 hours dark and light cycles. Feeding and drinking water were provided adlibitum with reference to standard feed. Except for the regular control group, the other group was given an injection of alloxan monohydrate according to Adeoye et al. (2017) with a slight modification (120 mg/kgbw, dissolved in $0.2 \mathrm{~mL} \mathrm{NaCl}$ ) intraperitoneally (i.p). Blood sugar measurement was performed using a glucometer (Roche, $\mathrm{CH}$ ) three days after alloxan is injected. Rats with blood glucose levels of $>200 \mathrm{mg} / \mathrm{dL}$ were included in a further trial for 21 days. Group I was allocated as the normal rats, group II was the hyperglycemic rats and did not receive any treatment as an alloxan control, group III was the hyperglycemic rats that received glibenclamide as much as $5 \mathrm{mg} / \mathrm{kgbw}$, while groups IV dan $\mathrm{V}$ was hyperglycemic rats were treated with PSBEE 150 and 300 $\mathrm{mg} / \mathrm{kgbw}$ orally, and lasted for 21 days (Maliangkay et al. 2018).

\section{RESULTS AND DISCUSSION}

\section{Phytochemical analysis}

Extraction process obtained 24.5 gr PSBEE with red color and distinctive aroma of pakoba bark. The results of the phytochemical analysis of PSBEE can be seen in Table 1.

Phytochemical test results show that the ethanol extracts from $S$. myrtifolium plants contain alkaloids, flavonoids, triterpenoids, and saponins (Haryati et al. 2015; Banerjee and Aziz 2018). The results of the Syzygium phytochemical test showed some similarities to the study of Kinho et al. (2011), which also contained alkaloids, flavonoids, and tannins. Syzygium cumini contains alkaloids, phenolics, and terpenoids (Sudarmi et al. 2017). Evendi (2017) reported that the methanol extract of $S$. polyanthum contained alkaloids, flavonoids, saponins, and tannins.

Table 1. Results of Phytochemical analysis of PSBEE

\begin{tabular}{lcc}
\hline \multicolumn{1}{c}{ Compound group } & Results \\
\hline Alkaloid & ++ \\
Flavonoid & ++ \\
Saponin & - \\
Tanin & +++ \\
\hline
\end{tabular}


Table 2. Minimal inhibitor zone formed

\begin{tabular}{lll}
\hline \multirow{2}{*}{ Concentration $(\%)$} & \multicolumn{2}{c}{ Inhibition zone $(\mathbf{m m})$} \\
\cline { 2 - 3 } & \multicolumn{1}{c}{$\boldsymbol{E}$ coli } & \multicolumn{1}{c}{ S. aureus } \\
\hline 0.1 & $0.1 \pm 0.003$ & 0 \\
0.3 & $0.29 \pm 0.004$ & 0 \\
0.5 & $0.4 \pm 0.003$ & $0.2 \pm 0.01$ \\
1 & $0.5 \pm 0.003$ & $0.47 \pm 0.057$ \\
2 & $0.7 \pm 0.003$ & $0.51 \pm 0.01$ \\
5 & $1.22 \pm 0.008$ & $0.53 \pm 0.06$ \\
10 & $1.71 \pm 0.005$ & $0.83 \pm 0.06$ \\
30 & $1.92 \pm 0.007$ & $1.03 \pm 0.06$ \\
50 & $2.16 \pm 0.17$ & $1.37 \pm 0.47$ \\
Cefradokxyl $100 \mathrm{mg} / \mathrm{L}$ & $4.55 \pm 0.22$ & $9.07 \pm 0.13$ \\
\hline
\end{tabular}

\section{Antibacterial assay}

PSBEE was inhibited the growth of $E$. coli and $S$. aureus (Table 2) with minimal inhibition zones formed. The measured inhibition zone formed was low however, the inhibition zone was observed to get increase as the concentration is increased. The highest inhibition zone formed was at a level of $50 \%$, which was obtained with an average inhibition zone of $2.16 \mathrm{~mm}$ against $E$. coli and 1.37 $\mathrm{mm}$ against $S$. aureus respectively (Table 2). The results of the PSBEE antibacterial activity test against $E$. coli and $S$. aureus can be seen in Table 2 .

This is the first report on the antibacterial activity test of PSBEE endemic to North Sulawesi. Previous studies reported that several Syzygium plant species have antibacterial activity properties (Mawan et al. 2018). S. polyanthum infusion extract of antibacterial exhibited activity against Bacillus cereus, Salmonella thypi, Trichophyton mentagrophytes, and Candida albicans (Kusuma et al. 2011) and the methanol extracts from $S$. polyanthum fruit have antibacterial activity against $E$. coli (Mawan et al. 2018). Fitri et al. (2017) reported that the ethanol extract of $S$. polyanthum leaves has antibacterial activity against Shigella dysenteriae. Several other Syzygium species were reported to have antibacterial action such as the ethanol, ethyl acetate and water extracts from $S$. cumini can inhibit the growth of E. coli, Salmonella typhi, Pseudomonas aeruginosa, and S. aureus (Kaur et al. 2017; Mohamed, Ali and El-Baz 2013; Shafi et al. 2002).

Methanol and water extracts in $S$. jambolanum has been reported to inhibit the growth of several Salmonella typhimurium, Pseudomonas aeruginosa, Klebsiella pneumoniae, E. coli, Bacillus subtilis, S. aureus (Chandrasekaran and Venkatesalu 2004; Mohanty and Cock 2010). Moreover, it has been shown that the leaf extract of Syzygium jambos L. is potent against the pathogenic Propionibacterium acnes (Sharma et al. 2013 ${ }^{\text {b). }}$. Djoukeng et al. (2005) reported that the leave extracts of $S$. guineense have significant antibacterial activity against $E$. coli, Bacillus subtilis dan Shigella sonnei.

The antibacterial strength of the extracts was determined by the size of inhibition zone formed. Antibacterial activity can be classified into four categories according to its inhibition zone: ( $\geq 20 \mathrm{~mm}, 10-20 \mathrm{~mm}, 5-10$ $\mathrm{mm})$ as very strong, strong, moderate, and weak respectively (Lingga et al. 2016). The inhibition activity criteria of PSBEE has weak inhibition activity because the inhibition zone produced $\leq 5 \mathrm{~mm}$.

The ability of an extract to inhibit microbial growth depends on the phytochemical content of the extract. Although classified as weak PSBEE, it can inhibit the growth of $E$. coli and $S$. aureus. Yet, it still remains a question of what was the mechanism of bacterial inhibition by antibacterial compounds contained in PSBEE. Several studies have reported that the content of alkaloids, flavonoids, and tannins in the genus Syzygium can inhibit the growth of pathogenic bacteria such as methanol extract of S. cumini leaves (Banerjee and Aziz 2018; Kaur et al. 2017). The content of flavonoid compounds in $S$. aromaticum can inhibit bacterial growth by deformation cell membrane and cell wall (El-Maati et al. 2016). Ajiboye et al. (2016) reported the antibacterial mechanism of Syzygium aromaticum by increasing superoxide radicals in bacterial cell membranes

\section{Antioxidant assay}

The DPPH method was most commonly used to test the antioxidant activity of samples in vitro, which benefits from its simple and fast process. The principle of the DPPH method is the interaction of antioxidants with free radicals from DPPH so that DPPH free radicals will form stable DPPH compounds. If all of the electrons in the DPPH free radical become pairs, the color changed from dark purple to yellow (Tukiran et al. 2018). Data percentage inhibition values can be seen in Table 3 .

The antioxidant activity of the DPPH method is expressed by $50 \%$ Inhibition Concentration or IC50, which shows the sample concentration that can inhibit DPPH activity by as much as 50\% (Sulistiany et al. 2016). Antioxidant activity can also be seen from the calculation of the value of the antioxidant activity index (AAI), which was obtained from the comparison between the concentration of DPPH solution and IC50 concentration of the sample. Antioxidant activity was based on the AAI value, indicated to be weak if the AAI value $<0.5$, moderate antioxidant activity 0.5-1, strong antioxidant activity $1-2$, and very strong antioxidant activity $>2$.

Table 3. Percentage of radial inhibition of DPPH PSBEE and ascorbic acid

\begin{tabular}{lcc}
\hline Sample & $\begin{array}{c}\text { Concentration } \\
(\mathbf{p p m})\end{array}$ & \% Inhibition \\
\hline \multirow{4}{*}{ PSBEE } & 50 & 37.28 \\
& 75 & 45.88 \\
& 100 & 52.5 \\
& 150 & 60.88 \\
& 200 & 69.78 \\
ascorbic acid & 250 & 85.07 \\
& 10 & 26.21 \\
& 12 & 28.57 \\
& 16 & 43.33 \\
& 20 & 50.48 \\
\hline
\end{tabular}


IC50 PSBEE value base on calculation results is 98,063 ppm, which has AAI value of 1.02, and ascorbic acid is $19.42 \mathrm{ppm}$, and the AAI value of ascorbic acid is 5.14. In this study, ascorbic is used as a comparison (Kaur et al. 2017). The use of contrast in testing antioxidants is to examine the strength of the antioxidant activity in PSBEE when compared with ascorbic. Based on the results above PSBEE is classified as a strong antioxidant.

The ability to inhibit DPPH radicals is due to the active compound contained in PSBEE. Phytochemical test results showed that PSBEE contains abundant alkaloids, flavonoids, and tannins. Our data is the first data that reports PSBEE antioxidant activity. Previous research has indicated that several species of the genus Syzygium have different antioxidant activities. Antioxidant activity of methanol extract of $S$. polyanthum leaves has IC50 44.35 $\mu \mathrm{g} / \mathrm{mL}$ thus was potential as an antioxidant (Hidayati et al. 2017). Sharma et al. (2017) reported the results of the enzymatic and non-enzymatic methods of antioxidant testing, where the methanol extract of $S$. cumini bark showed high antioxidant activity.

Syzygium cumini leaf was also reported to have scavenging activity against hydrogen peroxide and the antioxidant tested by FTC method showed a strong antioxidant activity (Kaur et al. 2017). S. cumini seeds also have strong antioxidant activity (Kumar et al. 2017) in line with the research conducted by Marliani et al. (2014). $S$. lanceolatum was also reported to have an antioxidant action (Muthumperuma et al. 2016). 3,4,3'-Tri-Omethylelagic acid, which was isolated from the chloroform fraction of Stem Bark of $S$. polycephalum showed antioxidant activity against DPPH with IC50 values of 163.6 for chloroform extract and 72.1 for compounds which have been isolated (Tukiran et al. 2018).

\section{Antihyperglycemic}

Data in the form of blood sugar levels in the regular group, alloxan, PSBEE $150 \mathrm{mg} / \mathrm{kgbw}$, and $300 \mathrm{mg} / \mathrm{kgbw}$ during treatment can be seen in Table 4 .

ANOVA analysis shows that there are differences in blood sugar levels based on the dose and length of treatment; there is also a relationship between the dose and the duration of administration of blood sugar in rats. Based on Table 4, alloxan can increase blood sugar, while glibenclamide can reduce the blood sugar of alloxaninduced rats. Administration of $150 \mathrm{mg} / \mathrm{kgbw}$ of PSBEE for 21 days can lower blood sugar in hyperglycemic rats as well as $300 \mathrm{mg} / \mathrm{kgbw}$ of PSBEE.

Herbal medicine is the oldest treatment method known by humans. This treatment method uses plant parts such as seeds, fruit, roots, bark, leaves, and even flowers for the treatment of a disease. Alloxan administration (120 $\mathrm{mg} / \mathrm{kgbw}$ I.P) induces makes hyperglycemic in rats within 72 hours. Alloxan is used to increase blood sugar toward experimental animals; rats, mice, rabbits, and dogs for experimental purposes (Etuk 2010). Alloxan has been well known to be causing damage to $\beta$-cells, entering through the GLUT2 glucose transporter. By interacting with intracellular thiol groups, especially in glutathione, alloxan in cells produces reactive oxygen species (ROS) in cyclic redox reactions with produced dialuric acid. This dialuric acid formation process produces ROS in the form of superoxide radicals, hydrogen peroxide, and hydroxyl radicals. Hydroxyl radicals are responsible for the apoptosis of these cells because beta cells have very low antioxidant defense abilities. (Lenzen 2008; Sharma et al. 2013a) As a result, insulin production will be insufficient so that glucose levels in the blood increase (Basiru et al. 2018).

In the positive control group that was given the standard diabetes drug, glibenclamide $5 \mathrm{mg} / \mathrm{kgbw}$, occurred a significant decrease in rats' blood glucose level was observed as expected. Glibenclamide is an oral hypoglycemic sulfonylurea derivative that works actively to reduce blood sugar levels (Balsells et al. 2015). Glibenclamide works mainly by increasing insulin secretion and acts to inhibit ATP-sensitive potassium channels in $\beta$-cells so that the depolarized cell membrane causes the opening of voltage-dependent calcium channels, allowing $\mathrm{Ca}^{2+}$ to enter the cytosol, and eventually stimulating insulin release (Serrano-Martín et al. 2006; Luzi and Pozza, 1997).

The ability to reduce blood glucose levels in PSBEE cannot be separated from the phytochemical content of PSBEE. Ethnomedically, pakoba bark has been used by the Minahasan people in North Sulawesi to lower blood sugar. Until now, there is still a lack of information that reports the activity of pakoba as antidiabetic, so the mechanism of reducing blood sugar by pakoba is still less understood. Previous studies have reported several species of plants from the genus Syzygium to have vigorous antidiabetic activity.

Table 4. Measurement of blood glucose levels in alloxan-induced rats by administration PSBEE

\begin{tabular}{lllll}
\hline \multirow{2}{*}{ Treatment } & \multicolumn{4}{c}{ Blood sugar levels } \\
\cline { 2 - 5 } & Day 0 & Day 7 & Day 14 & Day 21 \\
\hline Normal control & $95 \pm 5.83^{\mathrm{a}}$ & $94 \pm 9.06^{\mathrm{a}}$ & $88.4 \pm 4.92^{\mathrm{a}}$ & $87.8 \pm 9.09^{\mathrm{a}}$ \\
Alloxan & $434.8 \pm 45.67^{\mathrm{a}}$ & $417 \pm 35.34^{\mathrm{a}}$ & $446 \pm 94.03^{\mathrm{a}}$ & $461 \pm 45.76^{\mathrm{a}}$ \\
Glibenclamide & $406.8 \pm 67.23^{\mathrm{a}}$ & $178.4 \pm 98.54^{\mathrm{b}}$ & $113.8 \pm 31.09^{\mathrm{b}}$ & $118 \pm 14.26^{\mathrm{b}}$ \\
$150 \mathrm{mg} / \mathrm{kgbw}$ dose & $449 \pm 38.99^{\mathrm{a}}$ & $351 \pm 30.7^{\mathrm{b}}$ & $263.8 \pm 61.94^{\mathrm{c}}$ & $197.6 \pm 31.09^{\mathrm{c}}$ \\
$300 \mathrm{mg} / \mathrm{kgbw}$ dose & $450 \pm 38.11^{\mathrm{a}}$ & $377.4 \pm 48.7^{\mathrm{b}}$ & $240 \pm 42.49^{\mathrm{c}}$ & $95 \pm 36.56^{\mathrm{d}}$ \\
\hline
\end{tabular}

Note: Different letter(s) in each column indicated significant difference on $\mathrm{P}<0.05$. 
Water extract from $S$. cumini can significantly reduce the blood sugar of the hyperglycemic rat (Sharma et al. 2013b). Research conducted by Ajiboye et al. (2018b) reported that the content of $S$. cumini polyphenols extract which were given to hyperglycemic rats can reduce the activity of cholinesterase and increase the activity of superoxide dismutase, catalase, and glutathione peroxidase all of which are the natural antioxidants that fight oxidative stress. In addition, S. cumini polyphenols extract have antidiabetic activity by increasing liver glycogen, reducing glycated hemoglobin (HbA1C), regenerating $\beta$-cells increasing HOMA- $\beta$ index ( $\beta$-cell function), increasing sensitivity and synthesis of insulin, reducing glucose 6 phosphate activity and increased GLUT-2 expression and activity (Ajiboye et al. 2018 ${ }^{\mathrm{a}}$ ). The content of mycaminose in $S$. cumini leaves has also been reported to possess the same mechanism as glibenclamide to reduce blood sugar in the hyperglycemic rat (Syama et al. 2018). Syama et al. (2018) also reported that the methanol extract of $S$. cumini seeds lowers blood sugar by inhibiting the action of the $\alpha$ amylase, $\alpha$-glucosidase, glycation, and DPP-IV enzymes.

Ethanol extract of $S$. polyanthum leaf shows antihyperglycemic and antioxidant activity (Wahjuni and Wita 2017) in line with Kusuma et al. (2011) who reported the phytochemical content of the fruit and ethanol extract of $S$. polyanthum leaves had antioxidant activity. The combination of Andrographis paniculata and $S$. polyanthum was said to maintain and repair pancreatic cells that were damaged by alloxan (Widharna et al. 2015). Manaharan et al. (2012) reported that the isolated several flavonoid compounds in ethanol extracts of $S$. aqueum leaves, European-3-O-rhamnoside, and phloretin, have antihyperglycemic activity by inhibiting the activity of $\alpha$ amylase and $\alpha$-glucosidase. $S$. densiflorum fruit has antihyperglycemic activity by inhibiting the action of free radicals and $\alpha$-amylase (Krishnasamy and Muthusamy 2015). S. paniculatum can increase insulin secretion and repair damaged $\beta$ - cells (Konda et al. 2019). Arumugam et al. (2016) reported that the content of myricitrin (flavonoid-3-O-glycoside), which belongs to the flavonoid group in $S$. malaccense could inhibit the action of $\alpha$ glucosidase and $\alpha$-amylase, increase fat accumulation, and increase glucose absorption through increased adiponectin secretion.

The routine content and quercitrin in S. guineense leaves have antihyperglycemic activity by increasing intrahepatic glucose absorption and increasing hepatic glycogen while also inhibiting the action of $\alpha$-glucosidase (August et al. 2016). Another mechanism of Syzygium antihyperglycemic activity is by increasing superoxide dismutase, glutathione, and glutathione reductase in $S$. mundagam (Chandran et al. 2017) and S. calophyllifolium (Chandran et al. 2016). The content of quercetin, gallic acid and anthocyanin flavonoids in the apple wax of $S$. samarangense enhances the function of $\beta$-cells, thereby increasing insulin secretion as well as reducing oxidative stress (Khamchan et al. 2018), in line with the antihyperglycemic activity in S. aromaticum (Habtemariam 2019).
In this study, the ability of PSBEE is possible because of its high antioxidant content and its ability to repair damaged $\beta$-cells from PSBEE. The natural antioxidant contained in PSBEE reduces oxidative stress toward rats, which finally increases insulin production and insulin secretion of hyperglycemic rats. However, further research is necessary to determine the cellular and molecular mechanism of PSBEE antihyperglycemic effect.

In conclusion, pakoba stem bark ethanol extract showed the best antihyperglycemic activity at a dose of 300 $\mathrm{mg} / \mathrm{kgbb}$. It also has a strong antioxidant activity but has weak antibacterial activity against $E$. coli and $S$. aureus. The extract of pakoba stem bark ethanol is potential as a new antidiabetic drug. However, further research needs to be done to determine the mechanism of action and the content of active compounds from stem bark ethanol extract of pakoba bark.

\section{ACKNOWLEDGEMENTS}

The author thanks the Ministry of Research Technology and Higher Education of the Republic of Indonesia for the funding support this research with contract no. 115/SP2H/LT/DPRM/2019. We express our sincere thanks to dr. Alva Sahiri Alexander Supit, Ph.D. for language editing.

\section{REFERENCES}

Adeoye AT, Oyagbemi AA, Adedapo A D, Omobowale TO, Ayodele AE, Adedapo AA. 2017. Antidiabetic and antioxidant activities of the methanol leaf extract of Vernonia amygdalina in alloxan-induced diabetes in Wistar rats. J Med Plants Eco Dev 1: 1-12.

Ajiboye BO, Ojo OA, Akuboh OS, Abiola OM, Idowu O, Amuzat AO. $2018^{\mathrm{a}}$. Anti-hyperglycemic and anti-inflammatory activities of polyphenolic-rich extract of Syzygium cumini Linn leaves in alloxaninduced diabetic rats. J Evid Based Integr Med 23: 1-8.

Ajiboye BO, Ojo OA, Akuboh OS, Okesola MA, Idowu OT, Oyinloye BE, Talabi JY. 2018 . The protective effect of polyphenol-rich extract of Syzygium cumini leaves on cholinesterase and brain antioxidant status in alloxan-induced diabetic rats. Jordan J Biol Sci 11 (2): 163169.

Ajiboye TO, Mohammed AO, Bello SA, Yusuf II, Ibitoye OB, Muritala HF, Onajobi IB. 2016. Antibacterial activity of Syzygium aromaticum seed: Studies on oxidative stress biomarkers and membrane permeability. Microb Pathog 95: 208-215.

Alasalvar C, Shahidi F. 2009. Tree Nuts: Composition, Phytochemicals, and Health Effects. CRC Press, New York

Alhabsyi DF, Suryanto E. 2014. Aktivitas antioksidan dan tabir surya pada ekstrak kulit buah pisang Goroho (Musa acuminate L.). Pharmacon 3: 107-114. [Indonesian]

Arumugam B, Palanisamy UD, Chua KH, Kuppusamy UR. 2016. Potential antihyperglycaemic effect of myricetin derivatives from Syzygium malaccense. J Funct Foods 22: 325-336.

August J, Ezenyi IC, Mbamalu ON, Balogun L, Omorogbe L, Solomon F. 2016. Antidiabetic potentials of Syzygium guineense methanol leaf extract. J Phytopharmacol 5: 150-156.

Aziz A, Banerjee S. 2018. Phytochemical screening and antibacterial activity study of Syzygium cumini (Myrtaceae) seed extracts. Pharmatutor 6 (4): 70.

Balsells M, García-Patterson A, Solà I, Roqué M, Gich I, Corcoy R. 2015. Glibenclamide, metformin, and insulin for the treatment of gestational diabetes: a systematic review and meta-analysis. BMJ 350: h102. DOI: $10.1136 /$ bmj.h102..

Chandran R, George BP, Abrahamse H, Parimelazhagan T. 2017. Therapeutic effects of Syzygium mundagam bark methanol extract on 
type-2 diabetic complications in rats. Biomed Pharmacother 95: 167174.

Chandran R, Parimelazhagan T, Shanmugam S, Thankarajan S. 2016 Antidiabetic activity of Syzygium calophyllifolium in streptozotocinnicotinamide induced type- 2 diabetic rats. Biomed Pharmacother 82: 547-554.

Chandrasekaran M, Venkatesalu V. 2004. Antibacterial and antifungal activity of Syzygium jambolanum seeds. J Ethnopharmacol 91 (1): 105-108.

Convention on Biological Diversity. 2018. Indonesia Biodiversity Strategy and Plan 2015-2020. The Ministry of the National Development Planning, Indonesia.

Djoukeng JD, Abou-Mansour E, Tabacchi R, Tapondjou AL, Bouda H, Lontsi D. 2005. Antibacterial triterpenes from Syzygium guineense (Myrtaceae). J Ethnopharmacol 101 (1-3): 283-286.

El-Maati MFA, Mahgoub SA, Labib SM, Al-Gaby AMA, Ramadan MF. 2016. Phenolic extracts of clove (Syzygium aromaticum) with novel antioxidant and antibacterial activities. Eur J Integr Med 8 (4): 494 504

Etuk. 2010. Animals models for studying diabetes mellitus. Agric Biol J North Am 2: 130-134.

Fitri KSA, Ramdhani D, Mustarichie R. 2017. Comparative study on activities of anti bacillary dysentery Shigella dysenteriae of Syzygium polyanthum and Dracaena angustifolia leaves ethanol extracts. Asian J Pharm Clin Res 10 (2): 348-352.

Habtemariam S. 2019. Medicinal Foods as Potential Therapies for Type-2 Diabetes and Associated Diseases: The Chemical and Pharmacological Basis of Their Action. Academic Press, Salt Lake City.

Haryati N, Saleh C, Erwin. 2015. Uji toksisitas dan aktivitas antibakteri ekstrak daun merah tanaman pucuk merah (Syzygium Myrtifolium Walp.) terhadap bakteri Staphylococcus aureus dan Escherichia coli. Jurnal Kimia Mulawarman 13 (1): 35-40.

Hidayati MD, Ersam T, Shimizu K, Fatmawati S. 2017. Antioxidant activity of Syzygium polyanthum extracts. Indon J Chem 17 (1): 49.

Kaur AP, Singh K, Kaur R. 2017. The antioxidant and antimicrobial activity of Syzygium cumin leaves. Intl J Curr Microbiol Appl Sci 6 (2): 215-222

Khamchan A, Paseephol T, Hanchang, W. 2018. Protective effect of wax apple (Syzygium samarangense (Blume) Merr. \& L.M. Perry) against streptozotocin-induced pancreatic $\beta$-cell damage in diabetic rats. Biomed Pharmacother 108: 634-645.

Kinho J, Arini DID, Halawane J, Nurani L, Halidah, Kafiar Y, Karundeng MC. 2011. Tumbuhan Obat Tradisional di Sulawesi Utara. Balai Penelitian Kehutanan, Manado. [Indonesian]

Konda PY, Dasari S, Konanki S, Nagarajan P. 2019. In vivo antihyperglycemic, antihyperlipidemic, antioxidative stress and antioxidant potential activities of Syzygium paniculatum Gaertn. in Streptozotocin-induced diabetic rats. Heliyon 5 (3): e01373. DOI 10.1016/J.HELIYON.2019.E01373

Krishnasamy G, Muthusamy K. 2015. In vitro evaluation of antioxidan and antidiabetic activities of Syzygium densiflorum fruits. Asian Pac J Trop Dis 5 (11): 912-917.

Kumar A, Anu, Mohan A, Sharma NR, Rehman H. 2017. Antibacterial, antioxidant analysis of phytochemical extracts derived from seeds of Syzygium cumini L. against pathogenic bacteria. Res J Pharma Technol 10 (8): 2707-2712.

Kusuma IW, Kuspradini H, Arung ET, Aryani F, Min YH, Kim JS, Kim Y. 2011. Biological activity and phytochemical analysis of three Indonesian medicinal plants, Murraya koenigii, Syzygium polyanthum and Zingiber purpurea. J Acupuncture Meridian Stud 4 (1): 75-79.

Lenzen S. 2008. The mechanisms of alloxan- and streptozotocin-induced diabetes. Diabetologia 51: 216-226.

Lingga RA, Pato U, Rossi E. 2016. Uji antibakteri ekstrak batang kecombrang (Nicolaia speciosa Horan) terhadap Staphylococcus aureus dan Escherichia coli. JOM Faperta 3 (1): 1-15. [Indonesian]

Maliangkay HP, Rumondor R, Walean M. 2018. Uji Efektifitas antidiabetes ekstrak etanol kulit buah manggis (Gracinia mangostana L.) pada tikus putih (Rattus novergicus) yang diinduksi aloksan. Chemistry Progress 11 (1): 15-20. [Indonesian]

Manaharan T, Appleton D, Cheng HM, Palanisamy UD. 2012. Flavonoids isolated from Syzygium aqueum leaf extract as potential antihyperglycaemic agents. Food Chem 132 (4): 1802-1807.

Marliani L, Sari IN, Yuniarti S. 2014. Aktivitas antioksidan dan kandungan senyawa fenolat biji jamblang (Syzygium cumini (L.) Skeels). Jurnal Farmasi Galenika 1 (2): 43-47. [Indonesian]
Mawan AR, Indriwati SE, Suhadi S. 2018. Aktivitas antibakteri ekstrak metanol buah Syzygium polyanthum terhadap pertumbuhan bakteri Escherichia coli. Bioeksperimen: Jurnal Penelitian Biologi 4 (1): 64. Skeels). Jurnal Farmasi Galenika 1 (2): 43-47. [Indonesian]

Mohamed AA, Ali SI, El-Baz FK. 2013. Antioxidant and antibacterial activities of crude extracts and essential oils of Syzygium cumini leaves. PLoS ONE 8 (4): 1-7. PLoS One 8 (4): e60269. DOI: 10.1371/journal.pone.0060269.

Mohanty S, Cock IE. 2010. Bioactivity of Syzygium jambos methanolic extracts: Antibacterial activity and toxicity. Pharmacogn Res 2 (1): 49.

Muthumperuma C, Stalin NK, Das A, Sudhakar SP. 2016. Chemical profiling of leaf essential oil, antioxidant potential and antibacterial activity of Syzygium lanceolatum (Lam.) Wt. \& Arn. (Myrtaceae). Free Radic Antioxid 6: 13-22.

Ramadhan R, Kristanti AN, Amirta R, Kusuma IW, Phuwapraisirisan P, Haqiqi MT, Saparwadi. 2019. Screening for potential antidiabetes and antioxidant activities of selected plants from East Kalimantan, Indonesia. Biodiversitas 20 (7): 1820-1826.

Serrano-Martín X, Payares G, Mendoza-León A. 2006. Glibenclamide, a blocker of $\mathrm{K}^{+}$ATP channels, shows antileishmanial activity in experimental murine cutaneous leishmaniasis. Antimicrob Agents Chemother 50 (12): 4214-4216.

Singh B, Vijayakumar S. 2018. Evaluation of anti-diabetic activity of leaves of Syzygium cumini mono herbal formulation in Wistar. World J Pharm Pharm Sci 7: 1391-1397.

Shafi PM, Rosamma MK, Jamil K, Reddy PS. 2002. Antibacterial activity of Syzygium cumini and Syzygium travancoricum leaf essential oils. Fitoterapia 73 (5): 414-416.

Sharma B, Siddiqui MS, Kumar SS, Ram G, Chaudhary M. 2013a. Liver protective effects of aqueous extract of Syzygium cumini in Swiss albino mice on alloxan-induced diabetes mellitus. J Pharm Res 6 (8): 853-858.

Sharma R, Kishore N, Hussein A, Lall N. 2013b. Antibacterial and antiinflammatory effects of Syzygium jambos L. (Alston) and isolated compounds on acne vulgaris. BMC Compl Altern Med 13: 1-10.

Sharma Y, Mehrotra A, Kundu N, Srivastava NS. 2017. A Study of antibacterial, antioxidant and neuroprotective effect of stem of Syzygium cumini. Intl J Green Pharm 11: 5-9.

Situmeang B, Malik Ibrahim A, Bialangi N, Musa W, Silaban S. 2019. Antibacterial activity and phytochemical screening of Kesambi (Sapindaceae) against Escherichia coli and Staphylococcus aureus. Jurnal Pendidikan Kimia 11 (1): 14-17.

Sudarmi K, Darmayasa GBI, Muksin IK. 2017. Uji fitokimia dan daya hambat ekstrak daun juwet (Syzygium cumini) terhadap pertumbuhan Escherichia coli dan Staphylococcus aureus ATCC. Jurnal Simbiosis 5 (2): 47-51. Skeels). Jurnal Farmasi Galenika 1 (2): 43-47. [Indonesian]

Sulistiany H, Sudirman LI, Dharmaputra OS. 2016. Production of fruiting body and antioxidant activity of wild Pleurotus. Hayati J Biosci 23 (4): 191-195.

Syama HP, Arun KB, Sinumol G, Dhanya R, Suseela Anusree S, Nisha P, Jayamurthy P. 2018. Syzygium cumini seed exhibits antidiabetic potential via multiple pathways involving inhibition of $\alpha$-glucosidase, DPP-IV, glycation, and ameliorating glucose uptake in L6 cell lines. J Food Proc Preserv 42 (2): 1-13.

Tukiran T, Wardana AP, Hidayati N, Shimizu K. 2018. An ellagic acid derivative and its antioxidant activity of chloroform extract of stem bark of Syzygium polycephalum Miq. (Myrtaceae). Indon J Chem 18 (1): 26-34.

Wahjuni S, Wita IW. 2017. Hypoglycemic and antioxidant effects of Syzygium polyanthum leaves extract on alloxan-induced hyperglycemic Wistar rats. Bali Med J 3 (3): 113-116.

Walean M, Rumondor R, Maliangkay HP, Melpin R. 2018. Pengaruh pemberian ekstrak etanol kulit batang pakoba (Syzygium $\mathrm{sp}$ ) terhadap gambaran histopatologi ginjal tikus putih yang diinduksi etilen glikol. Chemistry Progress 11 (1): 29-34. Skeels). Jurnal Farmasi Galenika 1 (2): 43-47. [Indonesian]

Widharna R, Ferawati, Tamayanti W, Hendriati L, Hamid I, Widjajakusuma E. 2015. Antidiabetic effect of the aqueous extract mixture of Andrographis paniculata and Syzygium polyanthum leaf. Eur J Med Plants 6 (2): 82-91. 
BIODIVERSITAS

Volume 21, Number 6, June 2020

Pages: 2377-2382
ISSN: 1412-033X

E-ISSN: 2085-4722

DOI: $10.13057 /$ biodiv/d210606 